\title{
THE MICROENTERPRISING SIZE AND ACCEPTANCE OF ISLAMIC HEALTH INSURANCE (TAKAFUL) IN NORTHWESTERN NIGERIA
}

\author{
Mansur Ahmed Kazaure ${ }^{1}$ and Addul Rashid Abdullah ${ }^{2}$ \\ ${ }^{1}$ Universiti Putra Malaysia, Malaysia, ahmedkazauremansur@gmail.com \\ ${ }^{2}$ Universiti Putra Malaysia, Malaysia, addul@gmail.com
}

\begin{abstract}
Application of Theory of Planned Behavior (TPB) in Islamic Health Insurance (takaful) acceptance revealed mixed findings. Hence, the need for a moderating variable to explain the conflicting results. This paper examines the moderating role of size of microenterprise among the TPB variables. To achieve this end, quantitative methodology adopted through distribution of research questionnaires among the participants of the study. Results indicate that attitude, social influence, perceived behavioral control and size of microenterprises significantly influence Islamic Health Insurance (takaful) acceptance intention among microenterprises in northwestern Nigeria. The findings also revealed that size of microenterprise moderates the effect of social influence on Islamic Health Insurance acceptance intention, but it failed to moderate the influence of attitude and perceived behavioral control on Islamic Health Insurance acceptance intention in same context. It implied that size of microenterprises does not matter most in Islamic Health Insurance acceptance; nonetheless, the finding contributes to the Theories of Reasoned Action and Planned Behavior as it provides evidence on the significant moderating role of size on the effect social influence on Islamic Health Insurance acceptance intention among microenterprises.
\end{abstract}

Keywords: Attitude, Intention, Perceived Behavioral Control, Takaful, Size, Social Influence. JEF Classification: G21; G22; I13.

\author{
Article history: \\ Received : December 07, 2018 \\ Revised : May 3, 2019 \\ Accepted : April 23, 2019 \\ Available online : November 01, 2019 \\ https://doi.org/10.21098/jimf.v5i3.1153
}




\section{INTRODUCTION}

Theory of Reasoned Action (TRA) (Fishbein \& Ajzen, 1975) and Theory of Planned Behavior (TPB) (Ajzen, 1991) have been the most widely applied theories in understanding Islamic Health Insurance (takaful) acceptance (Amin, 2012; Rahim \& Amin, 2011; Husin \& Rahman, 2013; Souiden, Jabeur, \& Estelami, 2015; Mas'ud, 2016). The existing literature has extensively examined the key predictors of intention to accept takaful as an Islamic Health Insurance Services covering attitude, subjective norms and perceived behavioral control. Evidence has been clear that application of the TPB variables reveal conflicting findings (Corry, 2008). Hence, the need for moderating variable as suggested by Baron and Kenny (1986). Nonetheless, empirical evidence highlights strong influence of attitude on intention towards the acceptance of Takaful in Nigeria (Maiyaki and Ayuba, 2015; Mas'ud, 2016), but practically the acceptance of insurance including Takaful is just $0.6 \%$ (Delloitte, 2014), even though over half of the country's population are Muslims (Yusuf, 2012). Expectedly, the major market for Islamic Health Insurance will be private sector employees, since most of the public sector employees in Nigeria are covered by National Health Insurance Scheme (NHIS), though it has less 3\% coverage of the Nigerian population. This indicates the need for alternative Health Insurance Scheme to maximize social security of private sector employees who are less cover by NHIS.

Therefore, building on the above background, the paper attempts to extend the TPB to get explanation of the relevance of size of microenterprises in the acceptance intention of Islamic Health Insurance in Nigeria. The motives of the paper are threefold. First, the conflicting finding in TPB variables calls for examination of moderating variables; therefore, the size of microenterprise measured by number of employees is proposed here. Second, the low acceptance of insurance in Nigeria including Islamic Health Insurance despite acceptance intention and favorable attitude highlights the need for more evidence to enable the policymakers to have a set of guidelines for future policy decisions. Last, the low health insurance coverage in private sector indicate the need to explore the alternative for it employees. Hence, the need to study Islamic Health Insurance as an alternative health insurance methods for private sector employees.

In achieving the target of this paper, it has been divided into five parts, with this section as an introduction, followed by the second part as literature review. The third part is methodology and the fourth is result and discussion, while the last part being the conclusion, policy implication and limitation of the study.

\section{LITERATURE REVIEW}

\subsection{Islamic Health Insurance (takaful) and its Acceptance Intention}

Given the growing growths of the Islamic financial system, the Takaful industry has experienced important growth and developments, showing a clear appearance of the recognition of Islamic insurance as a vital source of enhancing the Sharia (Islamic law), which refers to an Islamic way of joint guarantee (Sherif \& Hussnain 2017).

According to Takaful Act of Malaysia, 'Takaful is a scheme grounded on brotherhood, joint assistance and solidarity, it offers financial assistance which is 
joint and offers help to policy holders when they are in need whereby program holders jointly agree to make a contribution for that purpose'. Subsequently, Takaful Insurance is considered as a device to provide some amount of financial defense against the calamities by way of compensation or a promise of benefit for specific possible losses in future in exchange for a payment sporadically (Sherif \& Hussnain 2017). Takaful can be distinguished from conventional insurance in five ways: the parties' right and obligations, contract, operational framework of

Takaful, status of nominee and the ownership of risks.

The intention toward action has its background in Islam. It was reported in a hadith that "actions are by intentions" (Al-Khattab). In applying this Hadith to the concept of Islamic Health Insurance, inference can be made that the actual participation into the scheme is only possible when there is intention. Thus, individuals with participation intention in the scheme are possibly those that will actually participate in the scheme. Modern behavioral theories, such as TRA (Fishbein \& Ajzen, 1975) and TPB (Ajzen, 1991) supported the Hadith through the postulation that is intention predict action/behavior and such is also predicted by the three variables covering attitude, subjective norms and perceived behavior control. The TRA of Fishbein and Ajzen (1975) proposed that attitude toward the behavior and subjective norms are the major predictors of intention towards certain behavior. Later, Ajzen (1991) considered the extension of TRA by integrating perceived behavior control which as defined as individuals evaluation of consequences of executing certain behavior. The theories were validated across context and settings (Armitage \& Conner, 2001; Godin \& Kok, 1996), and as well within the context of Islamic Health Insurance (takaful) (Amin, 2012; Rahim \& Amin, 2011; Husin \& Rahman, 2013; Souiden, Jabeur, \& Estelami, 2015), and more specifically in Nigeria (Maiyaki and Ayuba, 2015; Mas'ud, 2016). However, despite the empirical evidence that support the intention to accept Islamic Health Insurance, the actual growth is still low in Nigeria (Delloitte, 2014), specifically in the private sector that has the low coverage of the existing Health Insurance Scheme in the country. In addition to the known predictors of intention to accept Takaful in Nigeria and the relevance of private sector enterprises, this study seeks to explain the importance of size of microenterprises in the acceptance of Islamic Health Insurance, the outcome of which will provide highlight to the future policy making and operators on market segmentation. The next sections discuss develop hypotheses on the effect of attitude, social influence, and perceived behavioral control as well as the moderation effect of size of microenterprises on such effects.

\subsection{Attitude towards Takaful Acceptance}

Fishbein and Ajzen (1975) described attitude as feelings perceived by individuals when execution of certain which could be positive or negative. The feelings are evaluated by individuals based on his/her beliefs regarding consequential implication that will follow upon performance of that action. In an elaborative form, it covers the individuals' evaluation of desirability or otherwise of the penalty that could possibly follows execution of that behavior. In behavioral research, the major theories in the area such as in TRA and TPB have elaborately discussed the influence of attitude in influencing behavioral intention and the actual behavior 
(French et al., 2005). Subsequent meta-analytical reviews also confirmed the wellbuilt influence of attitude on actual behavior (Armitage \& Conner, 2001; Godin \& Kok, 1996).

Such influence of attitude on intention and behavior was also evidenced in Islamic Health Insurance literature, such as in Malaysia (Amin, 2012; Rahim \& Amin, 2011; Razak, et al., 2013; Husin \& Rahman, 2013), Tunisia (Souiden, Jabeur, \& Estelami, 2015), and Nigeria (Maiyaki and Ayuba, 2015; Mas'ud, 2016). However, the major weakness of the studies in Nigeria is lack of larger sample, concentration in one city, as well as inconsideration private sector enterprises, which have low insurance coverage and failure to examine the moderating effect of size in such relationship. In addressing the previously mentioned weaknesses, the following hypothesis has been proposed for validation in a larger setting of northwestern Nigeria and among microenterprises, whose employees have low insurance coverage in the region.

H1: Attitude towards Takaful will influence Islamic Health Insurance acceptance in Northwestern Nigeria.

\subsection{Social Influence on Takaful Acceptance}

The decision of families, friends, and community is of an important concern in individual's decision-making, and this is what refers to as social influence. It operationalized in this study as subjective norms, normative influence, community persuasion that can affect the individual's intention in accepting or not accepting Islamic Health Insurance. The key definition of social influence has been given by Fishbein and Ajzen (1975) in the TRA, which was considered as individual's expectation on those close to him/her that can perform a similar behavior. Indirectly, when an individual perceived that people close to him/her such as family, friends, and neighbors, immediate community would accept Islamic Health Insurance, there could be possibility on that person should equally accept the service.

Empirical literature on the effect of social influence on the intention to accept Islamic Health Insurance indicated that social influence has such high predictive power considered to other variables in TRA (Fauziah, Taib, Ramayah, \& Abdul Razak, 2008). Nonetheless, evidence from extant literature reported conflicting findings in relation to the effect of subjective norms on intention (Amin, 2012). In Nigeria, evidence is still lacking on the effect of social influence on intention to accept Islamic Health Insurance. Hence, the need for investigation. Consequently, it is proposed here that when individual is aware that families, friends, neighbors, and immediate community will accept Islamic Health Insurance there is the tendency for him or her to act in the same way. Consequently, the following hypothesis has been developed:

H2: Social influence will influence Islamic Health Insurance acceptance in Northwestern Nigeria.

\subsection{Perceived Behavioral Control on Takaful Acceptance}

The extension of TRA was what brought the perceived behavioral control into the TPB by Ajzen (1991). It has been defined as individual self-efficacy or ability to 
perform a certain action (Ajzen, 1991). Perceived behavioral control can be through one's control over certain action or confidence he/she possesses in executing such action. As a result, it brought about power of in-born confidence and situational confidence. In relation to Islamic Health Insurance, one can decide to accept it when he/she naturally likes the service while in some instance, it is the situation which individual find himself that can provide him the power to decide either to participate or not to participate in the service.

Through several meta-analytical reviews, evidence has been clear that perceived behavioral control is a strong factor that influences intention (Armitage \& Conner, 2001; Godin \& Kok, 1996; Kidwell \& Jewell, 2003). Specifically, in Islamic Health Insurance literature there is also evidence to that effect, such as in Malaysia (Amin, 2012; Rahim \& Amin, 2011; Husin \& Rahman, 2013), Tunisia (Souiden, Jabeur, \& Estelami, 2015), as well as in Nigeria (Maiyaki and Ayuba, 2015; Mas'ud, 2016). However, the major weaknesses of Nigerian studies are the small samples and concentration in one city, as well as inconsideration to private sector that has low health insurance coverage. Accordingly, the following hypothesis is proposed for validation using larger sample and private sector setting for which health insurance is equally desirable.

H3: Perceived behavioral control positively relates to Islamic Health Insurance acceptance in northwestern Nigeria.

\section{Potential Moderating Influence of Size of Microenterprises}

In Nigeria, microenterprises are defined as those having less ten (10) employees (SMEDAN, 2013). As such, the need to know the acceptance of Takaful by microenterpreneurs varies by the size of microenterprises they own/manage. It is logical to assume here that the larger the enterprises the more likely for its employees to join hand together to pressurize managers/owners of the enterprise to provide quality health services for then with health insurance easy and simple solution. Thus, with conflicting and mixed results in TPB variables (Corry, 2008), coupled with the suggestion of Baron and Kenny (1986) integrating moderator variable in resolving conflicting finding, size of microenterprises is considered here as potential moderator among the TPB variables. Therefore, the following hypotheses are proposed.

Hypothesis 4: Size of microenterprises has insignificant influence on Islamic Health Insurance acceptance in northwestern Nigeria.

Hypothesis 4a: Size of microenterprises moderates the influence of owner/managers' attitude towards Islamic financial products on Islamic Health Insurance acceptance. Specifically, the influence will be weaker microenterprises with small number of employees than those with larger number of employees.

Hypothesis 4b: Size of microenterprises moderates the effect of social influence on owner/ managers' Islamic Health Insurance acceptance. Specifically, the influence will be weaker microenterprises with small number of employees than those with larger number of employees.

Hypothesis 4c: Size of microenterprises moderates the influence of owner/managers' perceived behavioral control on Islamic Health Insurance acceptance. Specifically, the 
influence will be weaker microenterprises with small number of employees than those with larger number of employees.

\subsection{Theoretical Framework}

The framework proposed in this study has it theoretical background from two major behavioral theories: TRA developed by Fishbein and Ajzen (1975) and TPB developed by Ajzen (1991). As a theoretical contribution, and in consideration of the relevance of the private sector enterprises and its neglect in health insurance coverage, the size of microenterprises is propose as a potential moderator among the TPB variables. There are several reasons for this theoretical extension. First, the proponents of TRA and TPB made it opened for inclusion of any additional variable that can explain intention and subsequently behavior (Trivedi, 2005). As a result, this study considers the size of microenterprises on a potential moderator among TPB variables in line with the suggestions of the proponents of the theory. Second, conflicting findings and mixed results have been witnessed among the TPB variables (Corry, 2008). Coincidentally, Baron and Kenny (1986) suggested for the inclusion of moderating variables in resolving conflicting findings, accordingly, size of microenterprises is considered here as potential moderator. Last, the study will serve as an extension of studies in Nigeria that dwell on TPB as their underpinning theories, such studies include that of Maiyaki and Ayuba (2015) and Mas'ud (2016). The extension will equally address some of the weaknesses the studies such as small sample size, low geographical coverage, and lack of emphasis on private sector institutions that have low insurance coverage. Thus, it is expected that the proposed framework, which will be validated using owner/ managers' of microenterprises in northwestern Nigeria as potential respondents, will address the aforementioned weaknesses. The framework is depicted below in Figure 1.

Figure 1. Proposed Model for the Acceptance Islamic Health Insurance by Owners/ managers' of Microenterprises in Nigeria.

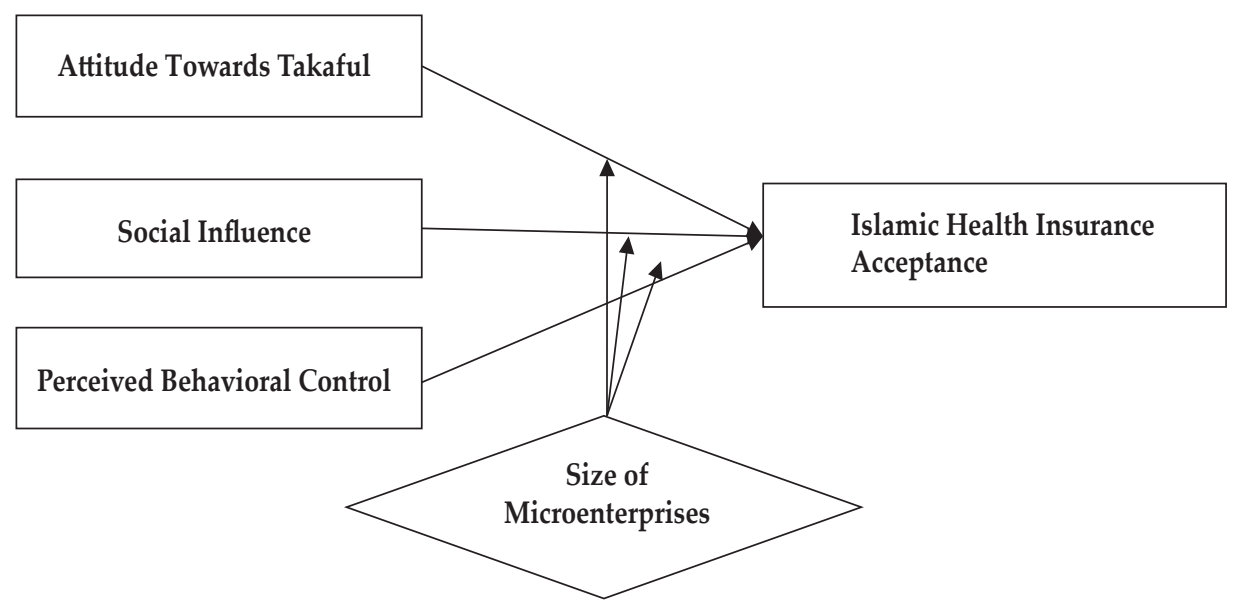




\section{METHODOLOGY}

\subsection{Area of the Study}

The study has a geographical coverage of northwestern Nigeria, which is the most populous region among the six geographical zones in the country and has the largest Muslim populations. It covers seven states of Jigawa, Kaduna, Kano, Katsina, Kebbi, Sokoto, and Zamfara. Moreover, the researcher undertook the study in November 2016, and SPSS was used for the description analysis, while ANOVA was used for the other statistical analysis.

\subsection{Subjects and Samples}

The subjects of the study were owners/managers of microenterprises in the region. As defined by Small and Medium Enterprises Development Agency SMEDAN (2013) microenterprises are enterprises having less than 10 employees. In Nigeria, there were 36,994,578 microenterprises (SMEDAN, 2013). Specifically, in the proposed area of study the number is contained in Table 1 below.

Table 1.

Population of Micro Enterprises in Northwestern Nigeria

\begin{tabular}{|c|c|c|}
\hline No. & State & No. of Micro Enterprises \\
\hline 1 & Kano & $1,700,000$ \\
\hline 2 & Kaduna & $1,600,000$ \\
\hline 3 & Katsina & $1,250,000$ \\
\hline 4 & Jigawa & 850,000 \\
\hline 5 & Zamfara & 700,000 \\
\hline 6 & Sokoto & 700,000 \\
\hline 7 & Kebbi & 700,000 \\
\hline Total & & $7,500,000$ \\
\hline
\end{tabular}

It was estimated by the Kriegcie and Morgan (1970) that any population above $1,000,000$ will have an approximate sample of 384 subjects. Therefore, with about $7,500,000$ populations, the sample in this study could equally be 384 . However, the sample was increased by $40 \%$ in line with previous studies in Nigeria (Alabede, 2012). Therefore, the final sample to which questionnaires were distributed was 540 owner/managers of microenterprises, though only 528 responded through the effort of the research assistants. The distributions of the questionnaire to the 540 respondents in the seven states are presented in Table 2. 
Table 2.

Proportionate Sample by State

\begin{tabular}{llcc}
\hline No. & \multicolumn{1}{c}{ State } & $\begin{array}{c}\text { No. of Micro Enterprises } \\
\text { with }<\mathbf{1 0} \text { employees }\end{array}$ & Sample \\
\hline 1 & Kano & $1,700,000$ & 123 \\
2 & Kaduna & $1,600,000$ & 115 \\
3 & Katsina & $1,250,000$ & 91 \\
4 & Jigawa & 850,000 & 61 \\
5 & Zamfara & 700,000 & 50 \\
6 & Sokoto & 700,000 & 50 \\
7 & Kebbi & 700,000 & 50 \\
\hline Total & & $7,500,000$ & 540 \\
\hline
\end{tabular}

The numbers are based on approximations from Fig. 40 of SMEDAN (2013) Report.

\subsection{Sampling Techniques}

A non-probability sampling technique was adopted. It can be justified on the premise that the lists of the 7,500,000 microenterprises in the region are not available. Consequently, purposive non-random sampling was used in which the research assistants approached the owner/managers of microenterprises that are reachable at the time of collecting the data.

\subsection{Data Collection}

Data were collected using a research questionnaire designed for the purpose. The questionnaires were designed using questions adopted and modified from Amin et al (2012), Maiyaki and Ayuba (2015) and Mas'ud (2016). For the purpose of the data collection, research assistants were deployed to each of the seven states that served as the area of the study. The period of data collection was one month; however, the research was conducts in 2017.

\subsection{Data Analysis}

Data were analyzed using hierarchical multiple regressions. In stage, one the dependent variable that is Takaful acceptance intention was regressed against the three independent variables (attitude towards Islamic financial products, social influence, and perceived behavioral control). In the second stage, the dependent variable will be regressed against the independent variables and the moderator (Size of firm). Lastly, in the third stage, the dependent variable will be regressed against the independent variable, moderator, and the interaction effects of independent variables and the moderator. The data analysis software to be used will be Special Package for Social Sciences (SPSS) version 19.0 and ANOVA. 


\subsection{Regression Models Specification}

For the purpose of the study, multiple regressions the models of the study are express as follows:

$$
\mathrm{IHIA}_{i}=\beta 0+\beta 1 \mathrm{ATT}_{i}+\beta 2 \mathrm{SI}_{i}+\beta 3 \mathrm{PBT}_{i}+\dot{\varepsilon}_{i}
$$

In this model the dependent variable, that Islamic Health Insurance acceptance (IHIA) will be regressed against three independent variables, attitude (ATT), social influence (SI), and perceived behavioral control (PBC). This model depicts clearly the original TPB with no extension. As a contribution of the current study, the TPB is extended through the integration of SIZE in eq.2.

$$
\mathrm{IHIA}_{i}=\beta 0+\beta 1 \mathrm{ATT}_{i}+\beta 2 \mathrm{SI}_{i}+\beta 3 \mathrm{PBT}_{i}+\beta 4 \mathrm{SIZE}_{i}+\dot{\varepsilon}_{i}
$$

SIZE as a potential moderator was introduce in eq. 2 and its interaction effect with ATT, SI and PBC is proposed in eq. 3 to test whether it significant matters and moderate the relationship proposed by TPB in eq.1.

$$
\begin{aligned}
& \operatorname{IHIA}_{i}=\beta 0+\beta 1 \mathrm{ATT}_{i}+\beta 2 \mathrm{SI}_{i}+\beta 3 \mathrm{PBT}_{i}+\beta 4 S_{i}+\beta 5 \text { ATTxSIZE }_{i} \\
& +\beta 6 \operatorname{SIxSIZE}_{i}+\beta 7 \text { PBTxSIZE }_{i}+\dot{\varepsilon}_{i}
\end{aligned}
$$

The objective of the study hinged on eq.3, which is the comprehensive model covering all the proposed hypotheses in 2.2 to 2.5 . As a result, it is the model for validation in the current study as it encompasses all the TPB variables and proposed extension of the theory through SIZE.

\section{RESULTS AND ANALYSIS}

In this part, the analysis of respondents' profile that indicates their characteristics was present and discussed. The results of descriptive analysis of the study's variable, normality of the data, multicolleanearity of the study's variables, fitness of the measures as well as the regression analysis have been present and discussed.

\subsection{Profile of Respondents}

The characteristics of the respondents relating to the gender, age, marital status, qualification, position, industry and size of the enterprises measured using number of employees are present in Table 3. 
Table 3.

Profile of Respondents

\begin{tabular}{|c|c|c|}
\hline Respondents Profile & Frequency & Percentage \\
\hline $\begin{array}{l}\text { Gender } \\
\text { Male } \\
\text { Female } \\
\text { Total } \\
\end{array}$ & $\begin{array}{l}416 \\
112 \\
528\end{array}$ & $\begin{array}{l}78.8 \\
21.2 \\
\mathbf{1 0 0}\end{array}$ \\
\hline $\begin{array}{l}\text { Age } \\
20-30 \text { Years } \\
31-40 \text { Years } \\
40 \text { Years and Above } \\
\text { Total } \\
\end{array}$ & $\begin{array}{l}144 \\
252 \\
122 \\
528 \\
\end{array}$ & $\begin{array}{l}27.3 \\
49.6 \\
23.1 \\
100 \\
\end{array}$ \\
\hline $\begin{array}{l}\text { Marital Status } \\
\text { Single } \\
\text { Married } \\
\text { Divorced } \\
\text { Separated } \\
\text { Total }\end{array}$ & $\begin{array}{c}214 \\
283 \\
24 \\
7 \\
528\end{array}$ & $\begin{array}{c}40.5 \\
53.6 \\
4.5 \\
1.3 \\
100\end{array}$ \\
\hline $\begin{array}{l}\text { Qualification } \\
\text { SSCE/GCE } \\
\text { ND/NCE } \\
\text { HND/BSC } \\
\text { Masters } \\
\text { Total }\end{array}$ & $\begin{array}{c}163 \\
205 \\
137 \\
20 \\
528\end{array}$ & $\begin{array}{c}30.9 \\
38.8 \\
25.9 \\
2.8 \\
100\end{array}$ \\
\hline $\begin{array}{l}\text { Position } \\
\text { Owner } \\
\text { Manager } \\
\text { Total }\end{array}$ & $\begin{array}{l}268 \\
260 \\
528\end{array}$ & $\begin{array}{l}50.8 \\
49.2 \\
\mathbf{1 0 0}\end{array}$ \\
\hline $\begin{array}{l}\text { Industry } \\
\text { Manufacturing } \\
\text { Service } \\
\text { Agriculture } \\
\text { Total } \\
\end{array}$ & $\begin{array}{l}122 \\
247 \\
159 \\
528\end{array}$ & $\begin{array}{c}23.1 \\
46.8 \\
30.1 \\
100 \\
\end{array}$ \\
\hline $\begin{array}{l}\text { Size-Number of Employees } \\
\text { One } \\
\text { Two } \\
\text { Three } \\
\text { Four } \\
\text { Five } \\
\text { Six } \\
\text { Seven } \\
\text { Eight } \\
\text { Nine } \\
\text { Total }\end{array}$ & $\begin{array}{c}39 \\
57 \\
47 \\
56 \\
54 \\
57 \\
57 \\
68 \\
93 \\
528\end{array}$ & $\begin{array}{c}7.4 \\
10.8 \\
8.9 \\
10.6 \\
10.2 \\
10.8 \\
10.8 \\
12.9 \\
17.6 \\
100\end{array}$ \\
\hline
\end{tabular}

It can be seen from the Table 3 that a male forms the majority of the respondents, and mostly were within the age of 31 to 40 years. Equally, most of the respondents are married and have either Diploma or National Certificate of Education. It was also evident that majority of the respondents were owners, and mostly operated within the service industry. Last, most of the microenterprises had up to nine employees. 


\subsection{Descriptive Statistics of Study Variables}

In Table 4, the descriptive analysis of the study's variable including minimum, maximum, mean and standard deviation is present.

Table 4.

Descriptive Statistics of Study Variables

\begin{tabular}{lccccc}
\hline Variables & N & Minimum & Maximum & Mean & Std. Deviation \\
\hline Intention & 528 & 1.00 & 5.00 & 3.70 & .95 \\
Attitude & 528 & 1.00 & 5.00 & 3.83 & .87 \\
Perceived Behavioral Control & 528 & 1.00 & 5.00 & 3.58 & .98 \\
Social Influence & 528 & 1.00 & 5.00 & 3.52 & 1.04 \\
Size of Microenterprises & 528 & 1.00 & 9.00 & 5.16 & 2.77 \\
\hline
\end{tabular}

The descriptive analysis in Table 4 revealed that 528 owner/managers responded to the study's questionnaires. It also revealed the clear picture of the measures used based on the Likert scale with minimum score of 1 and maximum of 5. The means scores for the study's variables range from 3.52 to 5.16; this is consistent with the standard deviation of 0.95 to 2.77. The mean values for the scale variables indicated that the respondents have moderate understanding of questions set in the data collection instruments.

\subsection{Test of Normality of the Data}

Normality of the data was test using graphical approach through visualizing the distribution using histogram. Therefore, Figure 2 presents that normality of the data using histogram.

\section{Figure 2. Histogram for Normality Test}

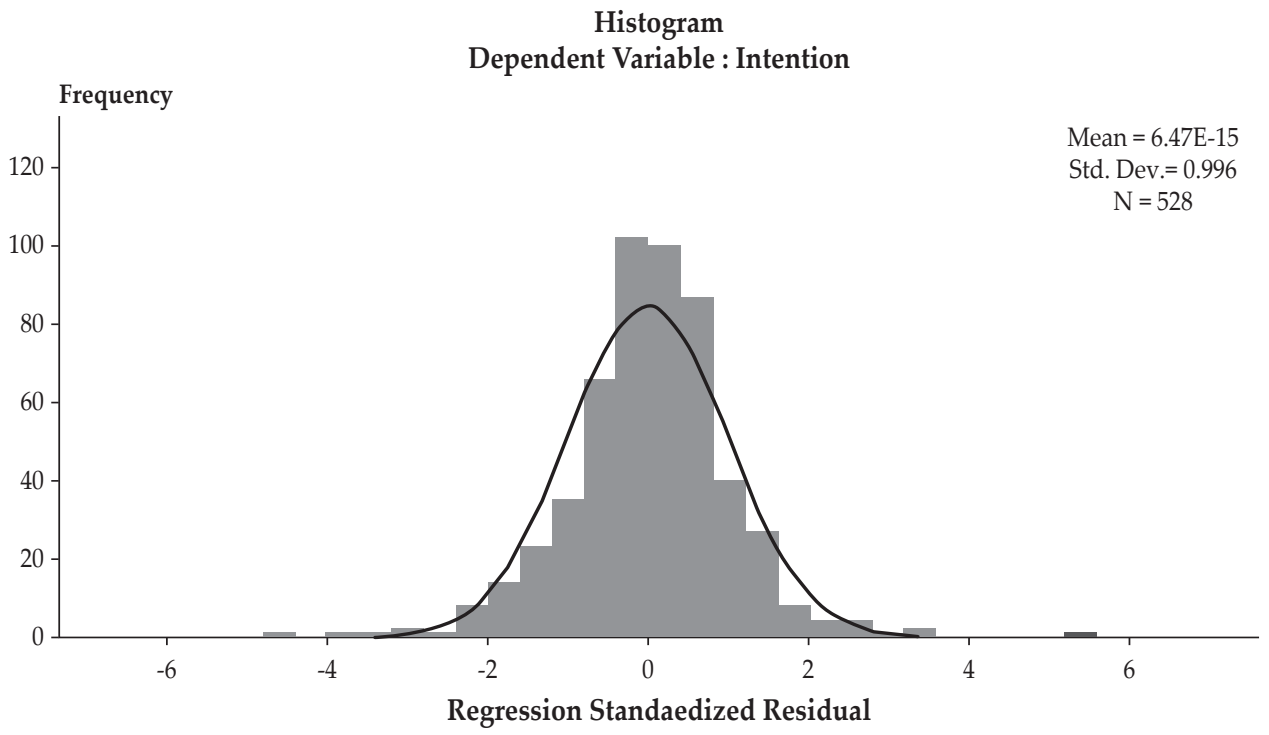


It is required that for data to be normally distributed, the histogram should depict bell-shaped. Evidence from Fig. 2 indicated that the bell-shaped is depict as required, accordingly, the data can be said to be normally distributed.

\subsection{Correlation Analysis}

Correlation analysis in one of the important postulations of multivariate analyses, it is required that the correction between study variables should not exceed 0.90 (Tabachnick \& Fidell, 2007), when exceed it indicate multicolinearity problem. The result of the analysis is present in Table 5.

Table 5.

\section{Correlation Analysis}

\begin{tabular}{lccccc}
\hline Variables & Intention & Attitude & Per.Beh.Con. & Social Influence & Size \\
\hline Intention & 1 & & & & \\
Attitude & $.833^{* *}$ & 1 & & & \\
Perceived Behavioral Control & $.741^{* *}$ & $.778^{* *}$ & 1 & 1 & \\
Social Influence & $.682^{* *}$ & $.677^{* *}$ & $.728^{* *}$ & $.190^{* *}$ & 1 \\
Size & $.249^{* *}$ & $.240^{* *}$ & $.196^{* *}$ & & \\
\hline$*$. Correlation is significant at the 0.01 level (2-tailed). & & &
\end{tabular}

Table 5 showed the result of correlation analysis. It is required that the correlation between independent variables should not be above 0.90 (Tabachnick \& Fidell, 2007). Thus, the result showed that there is no high level of correlation between the independent variables since the correlation is less than the cutoff value 0.90 .

\subsection{Test of Multicolinearity}

The test of multicolinearity is another important postulation multivariate analysis. It requires that two independent variables should not perform same job in a single regression model. The methods suggested by Hair et al (2013) for the test of multicolinearity are Variance Inflation Factor (VIF) and tolerance. As a result, it is used for testing the multicolinearity of the study's variables as presented Table 6.

Table 6.

Multicolinearity Test

\begin{tabular}{lcc}
\hline \multirow{2}{*}{ Variables } & \multicolumn{2}{c}{ Collinearity Statistics } \\
\cline { 2 - 3 } & Tolerance & VIF \\
\hline Attitude & .365 & 2.738 \\
Perceived Behavioral Control & .297 & 3.368 \\
Social Influence & .419 & 2.389 \\
Awareness & .552 & 1.810 \\
\hline
\end{tabular}


The result in Table 6 revealed that multiclinearity is not a problem in this analysis. It is required that when Tolerance is less than 0.20 and Variance Inflation Factor (VIF) is above 5, it is an indication of multicolinearity problem (Hair el at, 2013).

\subsection{Test of Reliability}

In order to measure internal consistency of the items of the study, Cronbach's Alpha was used. Based on the rules of a construct with high Cronbach's Alpha valve it shows that the contract has identical range and meaning (Cronbach 1971). The SPSS software was used for the reliability test and found that, the calculated reliability for each items ranged from .849 to .904 , this indicate that, all items should be retain because they are above the cut-off value of 0.5 .

Table 6.

Reliability Test

\begin{tabular}{llcc}
\hline S/N & \multicolumn{1}{c}{ Variable Name } & Cronbach's Alpha & No. of Items \\
\hline 1 & Intentions & .904 & 6 \\
2 & Attitude & .866 & 6 \\
3 & Perceive behavioral control & .849 & 3 \\
4 & Social influence & .849 & 3 \\
\hline
\end{tabular}

\subsection{Regression Analysis}

The regression analysis presented in Table 6 is based on the expanded model contained in 3.6 (i.e. eq.3). The expanded models contains the direct effects of attitude, social influence, perceived behavioral control, and size of microenterprises as well as the moderating effect of size of microenterprises on the relationship between attitude, social influence, perceived behavioral control, and Islamic health insurance acceptance.

Table 7.

Regression Analysis and Hypotheses Testing

\begin{tabular}{|c|c|c|c|c|c|c|c|}
\hline \multirow{2}{*}{$\begin{array}{l}\text { Hypotheses } \\
\text { Number }\end{array}$} & \multirow{2}{*}{ Relationship } & \multicolumn{2}{|c|}{$\begin{array}{c}\text { Unstandardized } \\
\text { Coefficients } \\
\end{array}$} & \multirow{2}{*}{$\begin{array}{c}\begin{array}{c}\text { Standardized } \\
\text { Coefficients }\end{array} \\
\text { Beta }\end{array}$} & \multirow{2}{*}{$t$} & \multirow{2}{*}{ Sig. } & \multirow{2}{*}{ Decisions } \\
\hline & & B & S. Error & & & & \\
\hline H1 & Attitude -> IHIA & .647 & .042 & .592 & 15.561 & .000 & Supported \\
\hline $\mathrm{H} 2$ & Social Influence -> IHIA & .154 & .039 & .170 & 4.801 & .000 & Supported \\
\hline H3 & Perc. Beh. Control -> IHIA & .134 & .039 & .139 & 3.385 & .000 & Supported \\
\hline $\mathrm{H} 4$ & Size -> IHIA & .014 & .008 & .042 & 1.761 & .019 & Supported \\
\hline $\mathrm{H} 4 \mathrm{a}$ & Size X Attitude -> IHIA & .004 & .014 & .010 & .260 & .398 & Not Supported \\
\hline $\mathrm{H} 4 \mathrm{~b}$ & Size X Per. Beh. Control -> IHIA & .010 & .014 & .033 & .719 & .236 & Not Supported \\
\hline $\mathrm{H} 4 \mathrm{c}$ & Size X Social Influ. -> IHIA & -.023 & .012 & -.077 & -1.969 & .025 & Supported \\
\hline
\end{tabular}

Note. IHIA is Islamic Health Insurance Acceptance 
From Table 7 it can be seen that hypothesis one which proposed that attitude towards Islamic Financial Products will influence Islamic Health Insurance acceptance in Nigeria was supported $(\beta=0.583, t=15.561, p=.000)$. Hypothesis two which postulated the effect of social influence on Islamic Health Insurance acceptance Nigeria was also supported ( $\beta=0.170, t=4.801, p=.000)$. The finding also supported the postulation that perceived behavioral control positively relates to Islamic Health Insurance acceptance in Nigeria $(\beta=0.139, t=3.385, p=.000)$. The postulation of hypothesis 4 which was that the size of microenterprise has a significant influence on Islamic Health Insurance acceptance Nigeria was also supported $(\beta=0.042, t=1.761, p=.019)$.

Hypothesis 5 projected that size of microenterprise moderates the influence of attitude towards Islamic financial products on Islamic Health Insurance acceptance. Specifically, the influence will be weaker for microenterprise with small number of employees than those will higher number of employees. The result does not support this postulation $(\beta=0.010, t=.260, p=.398)$. The hypotheses six projected that size of microenterprise moderates the effect of social influence on Islamic Health Insurance acceptance. Specifically, it postulated that the influence would be weaker for microenterprise with small number of employees than those will higher number of employees. Similar to hypothesis five, this postulation was not supported $(\beta=0.033, t=.719, p=.236)$. Lastly, hypothesis seven proposed that size of microenterprise moderates the influence of owner/managers' perceived behavioral control on Islamic Health Insurance acceptance. Specifically, the influence will be weaker for microenterprise with small number of employees than those will higher number of employees. Thus, the results support this hypotheses $(\beta=-0.077$, $t=-1.969, p=.025)$.

\subsection{Model Evaluation}

The model fitness was evaluated using the significance of the $f$ test, which evaluates whether the independents variables composed in the regressions fit in predicting the dependents variables. It is confirmed as the $f$ is significant at less than $1 \%$ $(0.000)$ highlighting the fitness of the variables composed in Table 7.

Table 8.

ANOVA Test for the Fitness of Regression Model

\begin{tabular}{lccccc}
\hline Model & Sum of Squares & Df & Mean Square & F & Sig. \\
\hline Regression & 345.663 & 7 & 49.380 & 202.278 & .000 \\
\hline $\begin{array}{l}\text { Predictors: (Constant), Attitude; Social Influence; Perceived } \\
\text { Attitude; Size X Perceived Behavioral Control; Size; Size X Social Influence; Size X }\end{array}$
\end{tabular}

The coefficient of determination ( $R$-squared) of the research model revealed good explanatory power of the independent variables on the dependent variable. The $R$-squared and adjusted $R$-squared of the model are $73.1 \%$ and $72.8 \%$, which indicates that $72.8 \%$ of the variation of intention to accept Islamic health insurance among microenterprises is explained by attitude of owner/managers, their social influence and perceive behavioral control as well as its interaction with the size 
of the microenterprises. However, the remaining $27.2 \%$ can be explained by other variables not contained in the research model.

Table 9.

R-Squared of the Models

\begin{tabular}{lcccc}
\hline Model & R & R Square & Adjusted R Square & Std. Error of the Estimate \\
\hline Regression & $.855 \mathrm{c}$ & .731 & .728 & .48409 \\
\hline Pron
\end{tabular}

Predictors: (Constant), Attitude; Social Influence; Perceived Behavioral Control; Size; Size X Social Influence; Size X Attitude; Size X Perceived Behavioral Control.

\section{CONCLUSION AND RECOMMENDATION}

\subsection{Conclusion}

The study investigates whether size of microenterprises matters in Islamic Health Insurance by owner/managers of the microenterprises in northwestern Nigeria. In achieving this end, the direct effect of attitude, social influence, perceived behavioral control and size on Islamic Health Insurance acceptance was investigated. It was found that attitude; social influence, perceived behavioral control and size significantly influence Islamic Health Insurance acceptance among the owner/ managers of microenterprises in Northwestern Nigeria. The result also revealed that size moderated the influence of individuals' perceived behavioral control on Islamic Health Insurance acceptance. However, it failed to moderate the effect of attitude and social influence on Islamic Health Insurance acceptance in the same context.

\subsection{Recommendation for Practitioner}

The study highlighted the potential market of Islamic Health Insurance based on factors that determine its acceptance by self-employed individuals. Thus, if the market turns worthwhile, that is a situation where there is good explanation for acceptance of Islamic health insurance, it will provide important insights to individuals and companies who may wish to operate Takaful insurance. Moreover, the research indicates that the market of Takaful is wide in microenterprise subsector due to lack of relevance of size in the acceptance of the service. Consequently, this will provide employment opportunities. With the creation of employment, it will assist in reducing poverty among those employed in this sector.

\subsection{Recommendation for Policy maker}

The study highlighted to the policy makers on ways and means of increasing health insurance coverage in Nigeria thereby reducing the suffering experienced by Nigerians especially self-employed individuals who are less capture in the NHIS scheme. Exploring this alternative will eventually increase the national health insurance coverage, which currently stands at only $3 \%$ of total Nigerian populations. 


\subsection{Recommendation for Academician}

Methodologically, the study extends of two theories, i.e. TRA and TPB, which were made open to including any additional predictor variable that can explain intention either directly or indirectly. It will also serve as reference material for future researchers in this area. In addition, the study adds to the existing literature on Islamic health insurance by adding size of the industry as moderator of the acceptance of the Takaful.

\subsection{Limitation of the Study}

The study has number of limitations, one of which being the concentration of the sample in major cities of the seven states considered as the study area. Another limitation was the convenience nature of the sample instead of using simple probability sample, the suggestion is that emphasis of future research should be given on the usage of probability sampling methods when the sampling frame is available as it is lacking during the conduct of this study. The consideration of other possible moderating variables is also suggested due to the failure of the size to serve as full moderator in the Theory of Planned Behavior in relation to the Islamic Health Insurance (takaful) acceptance and its determinants.

\section{REFERENCES}

Ajzen, I. (1991). The Theory of Planned Behavior. Organizational Behavior and Human Decision Processes, 50(2), 179-211.

Al-Khattab, U. i. Hadith. Sahih Bukhari 54.

Alabede, J. O. (2012). An Investigation Of Factors Influencing Taxpayers' Compliance Behaviour: Evidence From Nigeria Ph.D. Thesis Universiti Utara Malaysia.

Amin, H. (2012). An Analysis On Islamic Insurance Participation (Satu Analysis Entertain Insurance Islam). Jurnal Pengurusan, 34, 11-20.

Armitage, C. J., \& Conner, M. (2001). Efficacy Of The Theory Of Planned Behavior: A Meta-Analytic Review. British Journal of Social Psychology, 40(4), 471-499.

Ayuba, H. (2014). Non-Economic Factors Influencing the Islamic Insurance (Takaful) Services Consumption in Kano Metropolis, Nigeria. M.Sc. Dissertation, Bayero University Kano (BUK), Nigeria., Kano.

Baron, R. M., \& Kenny, D. A. (1986). The Moderator-Mediator Variable Distinction in Social Psychological Research: Conceptual, Strategic, and Statistical Considerations. Journal of Personality and Social Psychology 51(6), 1173-1182.

Corry, N. H. (2008). An Extended Model Of The Theory Of Planned Behavior: Predictive Value For Risky And Preventive Weight-Related Behaviors.

cronbach, L.J.(1971). Test Validation. R.L. Thorndike(Ed). EducationalMeasurement $2^{\text {nd }}$ ed. pp. 443-507. Washington, DC: American Council Education.

Delloitte. (2014). The Way Forward For Takaful - Spotlight On Growth, Investment, And Regulation In Key Markets. In H. El-Tahir (Ed.), The Deloitte ME Islamic Finance Knowledge Center (IFKC). The Kingdom of Bahrain.

Fauziah, Taib, M., Ramayah, T., \& Abdul Razak, D. (2008). Factors Influencing Intention To Use Diminishing Partnership Home Financing. International Journal of Islamic and Middle Eastern Finance and Management, 1(3), 235-248. 
Fishbein, M., \& Ajzen, I. (1975). Belief, Attitude, Intention and Behaviour: An Introduction to Theory and Research

French, D. P., Sutton, S., Hennings, S. J., Mitchell, J., Wareham, N. J., Griffin, S., . .. Kinmonth, A. L. (2005). The Importance Of Affective Beliefs And Attitudes In The Theory of Planned Behavior: Predicting Intention To Increase Physical Activity 1. Journal of Applied Social Psychology, 35(9), 1824-1848.

Godin, G., \& Kok, G. (1996). The Theory of Planned Behavior: A Review of Its Applications To Health-Related Behaviors. American journal of health promotion, 11(2), 87-98.

Husin, M. M., \& Rahman, A. A. (2013). A Review of Intention-Behaviour Theories: How Useful are These For Measuring Consumer Intention To Participate In Family Takaful. Insurance and Takaful Journal, 2013(1), 37-49.

Kidwell, B., \& Jewell, R. D. (2003). An Examination of Perceived Behavioral Control: Internal and External Influences On Intention. Psychology and Marketing(20), 625-642.

Krejcie, R. V., \& Morgan, D. W. (1970). Determining Sample Size For Research Activities. Educ Psychol Meas.

Maiyaki, A., \& Ayuba, H. (2015). Consumers' Attitude toward Islamic Insurance Services (Takaful) Patronages in Kano Metropolis, Nigeria. International Journal of Marketing Studies, 7(2), 27.

Mas' ud, A. (2016). Integrating The Moderating Effect Of Individuals'risk Vulnerability Into Takaful Acceptance Model: Evidence From A Frontier Market, $11^{\text {th }}$ International Conference of Islamic Economics and Finance, $11^{\text {th }}$ to $13^{\text {th }}$ December, Royale Chulan, Kuala Lumpur, Malayia.

Md Husin, M., \& Ab Rahman, A. (2013). What drives consumers to participate in family takaful schemes? A literature review. Journal of Islamic Marketing, 4(3), 264-280.

Nwachukwu, L. (2015). Boosting inclusive insurance in Nigeria via Takaful insurance. NANFeatures, 6(133).

Rahim, F. A., \& Amin, H. (2011). Determinants of Islamic insurance acceptance: An empirical analysis. International Journal of Business and Society, 12(2), 37-54.

Razak, M., Yusof, R., \& Ali, W. (2013). Acceptance determinants towards takaful products in Malaysia. International Journal of Humanities and Social Science, 3(17), 243-252.

Sherif, M. \&Hussaini (2017). Family Takaful in Developing Countries : the Case of Middle East and North Africa ( MENA ) Family Takaful in Developing Countries : the Case of Middle East and North Africa ( MENA ), (August).

Souiden, N., Jabeur, Y., \& Estelami, H. (2015). The impact of Islamic beliefs on consumers' attitudes and purchase intentions of life insurance. International Journal of Bank Marketing, 33(4), 423 -441.

Trivedi, V. U., Shehata, Mohamed \& Mestelman, Stuart, (2005). Attitudes, Incentives, and Tax Compliance. Canadian Tax Journal, 53(1), 29-61.

Yusuf, T. O. (2012). Prospects of Takaful's (Islamic Insurance) Contributions to the Nigerian Economy. Journal of Finance and Investment Analysis, 1(3), 217-230. 
This page is intentionally left blank 